Original Research Paper

\title{
Does Intellectual Capital Affect the Volatility of Returns? An Empirical Investigation on Italian Listed Companies
}

\author{
${ }^{1}$ Brett W. Cantrell, ${ }^{2}$ Daniela Coluccia, ${ }^{2}$ Stefano Fontana and ${ }^{2}$ Silvia Solimene \\ ${ }^{1}$ E.H. Patterson School of Accountancy, University of Mississippi, USA \\ ${ }^{2}$ University of Rome Sapienza, Rome, Italy
}

Article history

Received: 21-11-2017

Revised: 28-11-2017

Accepted: 2-12-2017

Corresponding Author:

Silvia Solimene

Dept. Business and Law,

University of Rome Sapienza,

Rome, Italy

Email: silvia.solimene@uniroma1.it

\begin{abstract}
In modern information economies, economic success increasingly depends on the ability to apply knowledge and to transform it into firm value. While intellectual capital plays a critical role in firm success, it is an intangible asset that is difficult to measure and that is unrecorded by the firm. Difficulties in measuring intellectual capital, as well as the dynamic nature of the firms that rely on it, may lead to greater stock market volatility/risk. Consistent with this expectation, in statistical tests we find that intellectual capital, measured by VAIC, positively relates to the volatility of stock returns section among Italian listed companies. We find this positive relation for two components of a firm's risk: systematic risk and specific risk. The finding is relevant to both investors concerned with understanding the risk/reward balance of particular investments and regulators concerned with market stability.
\end{abstract}

Keywords: Intellectual Capital, VAIC, Stock Price Volatility, Systematic Risk, Idiosyncratic Risk, Financial Markets

\section{Introduction}

Through time different factors have driven economic success, from economies built on land ownership to industrial capital to managerial capital. In the present era of information economics, economic success depends greatly on the ability to apply knowledge and to transform it into firm value (Zanda, 2012; Nuryaman, 2015). The intellectual capital associated with the key processes of capturing and applying information, while critical to success, is not reflected financial reporting. Thus, accounting systems suffer a serious disconnect with value in capital markets. This study examines how intangible intellectual capital relates to an important capital market construct, volatility. Specifically, the study examines how a firm's intellectual capital (measured with the Value Added Intellectual Coeffcient [VAIC]) relates to market volatility in the IFRS context.

The stock market plays a vital role in economic allocation of resources (Junkin, 2012), allowing companies to acquire capital easily and efficiently. Stock market price volatility is one of the most important aspects of financial markets, as it influences portfolio management, option pricing and market regulation (Poon and Granger, 2003). This study fills a gap in the extant literature by examining how systematic and idiosyncratic risk relate to intellectual capital for Italian listed firms on the Italian Stock Exchange. In Italy, listed companies must adopt IAS 38 when accounting for intangible assets. However, intellectual capital is an unrecorded intangible asset linked to structural, relational, human and stakeholder capabilities and relations. Thus, intellectual capital drives the economic performance of firm but is not recognized as an asset.

Given the significance of intellectual capital on the economics of a firm, we expect intellectual capital as measured by VAIC to explain price volatility beyond traditional market determinants and accounting determinants of price volatility. Specifically, we expect that firms with greater levels of intellectual capital experience greater stock price volatility, both relative to the market (beta) and idiosyncratically (standard deviation). Firms that rely on intellectual capital may experience greater return volatility because measuring intellectual capital is challenging (Volkov, 2012; Petty and Guthrie, 2000) and uncertainty in the value of intellectual capital creates uncertainty in the markets. Similarly, Lev (2000) notes that intangible assets are generally higher risk than physical or financial assets. Finally, increases in the dynamism and speed of information flows associated with knowledge economies (and intellectual capital) can lead to higher idiosyncratic risk/volatility (Campbell et al., 2001). 
We gather data from three years, 2006, 2011 and 2016, to reflect three different economic moments: before financial crisis (2006); during the sovereign European debt crisis (2011); and after the crisis (2016) as well as after the introduction of Quantitative Easing (QE) by the European Central Bank. Consistent with our predictions, we find that higher levels of intellectual capital measured by VAIC correlate to greater market risk/volatility (beta) and to greater idiosyncratic risk/volatility (standard deviation).

Understanding the relation between intellectual capital and price volatility will be useful to investors concerned with the risks inherent in their investments, as well as, market regulators concerned with market stability. This study also contributes to the academic literature, by providing the first evidence of the relation between VAIC and a critical market characteristic. While previous literature mainly focuses on the relationship between intellectual capital and firm performance/value (Tudor et al., 2014; Sumedrea, 2013; Poraghajan et al., 2013; Maditinos et al., 2011), we provide the first evidence of VAIC's relation to price volatility. This finding enriches investors' understanding of valuation creation from intellectual capital as value must be understood in the context of the risks taken to achieve it. Finally, given the limitations of Tobin's q to capture and explain the value of intellectual capital (Pamela and Mark, 1993), we build on recent literature that relates intellectual capital (measured by VAIC) to Tobin's q (Hejazi et al., 2016; Alshubiri, 2015) by relating VAIC to market measures of risk. Nuryaman (2012) considers market performance measures better than financial performance measures in depicting the value of intellectual capital elements. Thus, market based measures of risk should correspond to a firm's capabilities in converting resources into profits (including the capabilities around intellectual capital) and investors' perceptions of the firm.

The remainder of the paper is organized as follows: the first section summarizes the prior intellectual capital literature and the components of volatility of firms. Then a section formally states our hypothesis. Next, there are explained data and methodology employed. Following a section reports empirical results and finally a conclusion section.

\section{Literature Review}

\section{Intellectual Capital}

As the global economy has evolved into a knowledge-based economy, intangible assets have been widely recognized as the driving force of an economy's productivity growth and have become more and more crucial for a firm's survival and prosperity (MartinezTorres, 2006). Increasingly firms primarily rely on knowledge and intellectual capital rather than physical and financial resources (Stewart, 1997; Hayton, 2005). Wu et al. (2006) claim that intellectual capital has replaced physical and financial resources. Goldfinger (1997) suggests that the source of economic value and wealth is no longer the production of material goods but the creation and manipulation of intangible assets. Research has shown that firm value in the knowledge economy lies largely in IC rather than production and sales (Sullivan and Sullivan, 2000). Additionally, IC does not decrease in value with usage (Kong, 2008).

The increasing importance of intellectual capital, as a strategic asset capable of generating a sustainable competitive advantage over time, leads to the need for an acceptable measurement model, as traditional financial tools do not capture the relevant intellectual capital concepts (Volkov, 2012; Sullivan and Sullivan, 2000). In fact, in the IC field it is commonly understood that traditional financial measurement systems are inadequate for today's businesses (Pulic 2004). However, a review of the literature on intellectual capital shows that measuring intellectual capital is difficult and challenging.

In response to the increase in importance of intellectual capital and a desire to understand its role in corporate growth and value creation, researchers face two key challenges: (1) adequately defining intellectual capital and (2) measuring the contribution of intellectual capital to firm value.

Some have proposed defining intellectual capital as the entire difference between the market value and the book value of the equity of a firm (a sort of unidentifiable goodwill, according to Lev and Zarowin, 1999; Stewart, 1997; Sveiby, 1997; Salchi et al., 2014). Nunamaker et al. (2002) define IC as the knowledge acquired and utilized by organizations, which is held in the minds of its members, embodied in its procedures and processes and stored in its digital and non-digital media.

Others see intellectual capital as the sum of elements/components, which should be identified and measured separately. In keeping with this perspective, in recent years intellectual capital has been integrated by adding several new components to the traditional mixture of human capital, structural capital and relational capital (Bontis, 1998; Edvinsson and Malone, 1997). Based on this new interpretation, intellectual capital can be regarded as a set of knowledge assets that are acquired and controlled by the business and are the important mechanism for value creation (Alipour, 2012).

A more detailed consideration might include other dimensions of intellectual capital, such as renewal capital (Kianto et al., 2010), entrepreneurial capital (Erikson, 2002) and trust capital (Mayer et al., 1995). Schiuma and Lerro (2008) and Cassiman and Veugelers (2006) define intellectual capital broadly as the sum of components: human, structural, organizational, social and stakeholder capital. 
As for the second challenge of measuring intellectual capital, several models have been proposed by past literature. Brennan (2001) summarizes the prevailing intellectual capital models. One such model simply measures the difference between the book value and the market value of a company. This approach relies on the market to adequately understand and collectively value intellectual capital, an assumption that is hampered by difficult to evaluate "hidden" intangible assets. A second model, the "Skandia Navigator System" (Edvinsson, 1997) decomposes intellectual capital into five key dimensions of the business (1. Financial; 2. Client; 3. Human; 4. Processes; 5. Renewal and Development). A third approach, developed by Roos et al. (1997) also develops an IC-Index across several dimensions. More recently, Appuhami and Bhuyan (2015) note that three models of intellectual capital rise to prominence: the market to book value ratio $(\mathrm{M} / \mathrm{B})$, Tobin's q (Bontis, 1998) and value added intellectual coefficient (VAIC) (Pulic, 2000). VAIC values intellectual capital by calculating and combining various ratios of financial profitability to resources, thus the VAIC indicator ccan measure the real value of a company and its future abilities. VAIC has become the most used intellectual capital measure in the literature over the last decade (Volkov, 2012). Other methods to value intellectual capital include Economic Value Added (EVA) and the Balanced Score Card (BSC). Pulic (2004) argues that EVA focus on the efficiency of just one resource, capital employed and therefore this method can not be a valid measuring system for the new economy. The descriptive nature of the BSC and the lack of comparability in the non-monetary indicators that is favors, make BSC an in adequate valuation method for intellectual capital (Daum, 2002).

The shift to a knowledge-based economy severs the link between the cost of intangible asset and the value it generates. VAIC focuses on the creation of value from intellectual capital from three different types of inputs: physical and financial capital, human capital and structural capital (Firer and Williams, 2003; Pulic, 2000). This notion of value has outperformed typical financial metrics, such as ROI and ROE, especially when estimating the creation and destruction of value over time.

With VAIC as a starting point, several papers have further developed the VAIC measure (Volkov, 2012). Chen et al. (2004) examine the relationship between the various components of intellectual capital. Wang and Chang (2005) implemented this model of value by adding the relationship between the components of intellectual capital and the performance of the enterprise (Volkov, 2012), thus highlighting the sensitivity of the company's success with the VAIC and the competitive advantage that comes from it. Laing et al. (2010) further extend the Pulic model by documenting the contribution to the growth in intellectual capital. Following prior literature we use the VAIC measure to proxy for the value of intellectual capital in this study.

\section{Stock Price Volatility}

Stock price volatility is a well known proxy for the perceived risk by investors. It is also an indicator of changes in trends in the market place. Engle (1982) finds that information serves as an important cause of volatility, which can affect or alter the expected return on asset. Volatility rises also in presence of modifications in macroeconomic policies, which can increase uncertainty among investors. Volatility is a statistical measure of the dispersion of returns for a given security or market index, which can either be measured by using the standard deviation or variance between returns from that same security or market index. Commonly, the higher the volatility, the riskier the security.

One measure of the relative volatility of a particular stock to the market is its beta. A beta approximates the overall volatility of a security's returns against the returns of a relevant benchmark (usually the S\&P 500). In finance, the beta ( $\beta$ or beta coefficient) of an investment indicates whether the investment is more or less volatile than the market as a whole. In general, a beta less than 1 indicates that the investment is less volatile than the market, while a beta more than 1 indicates that the investment is more volatile than the market. Volatility is measured as the fluctuation of the price around the mean: the standard deviation. Beta is important because it measures the risk of an investment that cannot be reduced by diversification. It does not measure the risk of an investment held on a stand-alone basis, but the amount of risk the investment adds to an already-diversified portfolio. In the capital asset pricing model, beta risk is the only kind of risk for which investors should receive an expected return higher than the risk-free rate of interest (Fama, 1976). "Changes in a company's stock price may be partly attributable to a set of macroeconomic variables, such as changes in interest rates, inflation and national productivity, which are common factors because they affect the prices of most stocks in that market. These items are considered market risk components" (Sällebrant et al., 2007, p. 1472).

In finance, volatility $(\sigma)$ is the degree of variation of a trading price series over time as measured by the standard deviation of logarithmic returns. Historic volatility is derived from the time series of past market prices. An implied volatility is derived from the market price of a market traded derivative (in particular an option). It measures the unsystematic risk, also known as idiosyncratic risk or diversifiable risk, on a portfolio of assets. Unsystematic risk is the risk associated with individual assets, which (unlike market risk) can be diversified away to smaller levels by including a greater number of assets in the portfolio (specific risks "average 
out"). "Changes in stock price may be affected by the firm's success and performance, which include items like new product innovations, cost-cutting efforts, a disastrous fire at a manufacturing plant, or the discovery of an illegal corporate act. These components of return are considered firm-specific or idiosyncratic components because they affect only that firm and not the returns of other investments stocks in the market" (Sällebrant et al., 2007, p. 1473).

According to the Modern Portfolio Theory (MPT) by Markowitz (1952), investors are risk adverse, meaning that given two portfolios that offer the same expected return, investors will prefer the less risky one. Thus, an investor will take on increased risk only if compensated by higher expected returns. Conversely, an investor who wants higher expected returns must accept more risk. The exact trade-off will be the same for all investors, but different investors will evaluate the trade-off differently based on individual risk aversion characteristics. The implication is that a rational investor will not invest in a portfolio if a second portfolio exists with a more favorable risk-expected return profile - i.e., if for that level of risk an alternative portfolio exists that has better expected returns. Investors can reduce their exposure to individual asset risk by holding a diversified portfolio of assets. Diversification may allow for the same portfolio expected return with reduced risk. The portfolio's risk is a complicated function of the variances of each asset and the correlations of each pair of assets. To calculate the risk of a four-asset portfolio, an investor needs each of the four assets' variances and six correlation values, since there are six possible two-asset combinations with four assets. Because of the asset correlations, the total portfolio risk, or standard deviation, is lower than what would be calculated by a weighted sum.

From a managerial and accounting perspective, stock return volatility at a firm level is important to managers, since volatility affects the cost of capital. Volatility is also critical to shareholders as they must understand the risks inherent in their investments to ensure a proper balance between risk and reward. The real concern to investors is the systematic risk, In fact, investors get rewarded for bearing systematic risk. It is not total variance that affects expected returns, but only that part of the variance in returns that cannot be diversified away (Sällebrant et al., 2007).

\section{Hypothesis Development}

The finance and economics literature also explores with the linkages between intellectual capital and both profitability and the stock market (Tudor et al., 2014; Sumedrea, 2013; Poraghajan et al., 2013; Maditinos et al., 2011). For example, Daniel and Titman (2006) show that stock returns on markets are not linked to past financial performance of past years but to intangible information about future returns. However, prior literature provides little evidence around the relation between intellectual capital and stock market volatility. Sällebrant et al. (2007) conduct a small sample analysis using an adjusted intellectual capital rating based on firm's disclosures. The authors show that disclosure transparency around intellectual capital reduces idiosyncratic risk but increases systematic risk. This study adds to the literature by examining the relation between measures of intellectual capital (VAIC) and stock market volatility (beta and standard deviation of returns).

Campbell et al. (2001) demonstrates that while aggregate market and industry variances have been stable (updating and confirming Schwert's 1989 finding that market volatility did not increase in the period 1926/1997), firm level variance displays a large and significant positive trend, actually doubling between 1962 and 1997. The authors claim that this increase relates to the impact of the information technology revolution and the increasing speed of information flows. Additionally, Mazzucato and Tancioni (2007; 2012) show that industries in periods of dynamic innovation experience greater market volatility. If information economies where success is driven by intellectual capital are more dynamic we would expect the extent of a firms' reliance on intellectual capital to be associated with greater market volatility.

Additionally, as discussed in literature review section, intellectual capital is difficult to measure and not reflected in traditional reporting systems (Sullivan and Sullivan, 2000). Lev (2000, p. 42) notes that "the level of risk associated with intangibles is, in general, substantially higher than that associated with most physical and financial assets." While firms with high intellectual capital are more likely to succeed in converting resources in profits, the increase in the information complexity of this intangible asset increases the difficulty in making financial forecasts. Information asymmetry generally leads to greater volatility (Coluccia et al., 2017). Thus, the uncertainty around the value of intellectual capital could drive volatility in stock prices.

For these reasons, we formally state the following hypothesis:

\section{H1: Firms with higher levels of intellectual capital will experience greater stock market volatility. Abbreviations and Acronyms}

\section{Data and Methodology}

\section{Sample Selection}

We collected financial and market variables from three years, 2006, 2011 and 2016, to reflect three different economic moments: before financial crisis (2006); during the sovereign European debt crisis 
(2011); and after the crisis (2016) as well as after the introduction of Quantitative Easing (QE) by the European Central Bank. We collect this information for a homogenous sample composed of industrial companies from Italian Stock Exchange in Milan.

We excluded financial intermediaries, insurance companies and football clubs because of their different financial reporting standard sets. We also excluded companies listed after 12/31/2006 and those in the process of delisting during the period 1/1/2017$12 / 31 / 2016$. We also eliminated several companies for which the documents were not available for the periods in question. Thus, we obtained a sample of 130 firms with 390 firm-year observations. We chose a homogeneous and balanced panel of firm to understand their behavior in terms of risk exposure and VAIC over the period 2006, 2011 and 2016.

\section{Variable Measurement}

The dependent variable in our statistical tests, volatility or risk is measured both by the beta factor (Sharpe, 1964) which represents the non-diversifiable risk (also known as systematic risk or market risk) and by the standard deviation of stock price (as specific or idiosyncratic risk at a firm level). This is to say that the variance of a security includes both systematic and specific portion of risk, the sum also known as "Total Risk" (Elton et al., 2003; Goyal and Santa Clara, 2003). Both measures are well established in the finance literature with higher values corresponding to riskier securities.

Specifically, Beta is estimated each year as the regression coefficient of the stock's return on the market's return along the previous two years. We calculate the standard deviation of stock returns on weekly equity returns in years 2006 and 2016.

The critical independent variable of interest in our tests is the VAIC measure developed by Pulic (2000) and used extensively in the intellectual capital literature. The VAIC measure is derived from the firm's financial accounting and thus serves as a more objective measure than indices developed from discretionary disclosures. In the present paper, we estimate VAIC by applying Pulic's formula:

$$
V A I C=I C E+C E E
$$

Where:

$V A I C=$ The value of intellectual coefficient

$I C E=$ The intellectual capital efficiency coefficient (estimated by the difference between HCE [human capital efficiency coefficient] and SCE [structural capital efficiency coefficient]);

$C E E=$ The capital employed efficiency coefficient.

\section{Statistical Model}

To test our hypothesis, we performed a multivariate regression analysis by relating the dependent variables (beta or standard deviation) to the explanatory variables identified below. The regression can, therefore, be summarized in the following multivariate model:

$$
\begin{aligned}
\text { Beta }=a+ & \beta_{1} \text { VAIC }+\beta_{2} R O E+\beta_{3} \text { Lev } \\
& +\beta_{4} L N A+\beta_{5} T Q+\beta_{6} \text { Age }+\beta_{7} D O L+\varepsilon \\
\text { St.Dev. }=a+ & \beta_{1} \text { VAIC }+\beta_{2} R O E+\beta_{3} L e v \\
& +\beta_{4} L N A+\beta_{5} T Q+\beta_{6} \text { Age }+\beta_{7} D O L+\varepsilon
\end{aligned}
$$

Where:

$$
\begin{array}{ll}
\text { Beta } & =\text { The market risk } \\
\text { Std. Dev. } & \text { The specific risk } \\
V A I C & =\text { The value added intellectual coefficient } \\
\text { ROE } & =\text { The return on equity } \\
\text { Lev } & =\text { The leverage (financial debt/equity) } \\
L N A & =\text { The natural logarithm of total assets } \\
T Q & =\text { Tobin's Q; Age is the firm age estimated as } \\
& \text { the number of years since listing } \\
D O L & =\text { The degree of operating leverage }
\end{array}
$$

Before carrying out the regressions, we verified the possible multicollinearity between explanatory variables using the Variance Inflation Factor (VIF). In addition, we used the robust standard error clustered at the firm level (HAC). The regressions were performed using the OLS model. The Breusch-Pagan test attested that this model is preferable to the random effects panel model and the Hausman test attested that the panel model was preferable to random effects with regard to the fixedeffects panel model.

As noted, VAIC is the variable of interest for the study. A significant and positive coefficient estimate for $\beta_{1}$ in both equation (1) and (2) would provide support for our hypothesis that firms with higher intellectual capital will experience greater stock market volatility. In each model we also include a set of control variables identified in the prior literature as related to stock market volatility, either beta or the standard deviation of stock returns or both. For consistency, we include the same controls in each model. Table 1 lists the independent variables in the models with predicted signs.

Wei and Zhang (2006) show that ROE negatively relates to stock return volatility. Thus, firms with stronger financial performance experience less volatility in the market. We also control for leverage as firms with higher leverage should experience greater volatility (for a given level of asset risk) under the Modigliani-Miller Theory (1961). However, empirical investigations into the relation between leverage and volatility provide mixed results (Christie, 1982; Wei and Zhang, 2006; Brandt et al., 2010; Bartram et al., 2015). 
Table 1: Variables used in empirical models

\begin{tabular}{llll}
\hline Explanatory variables & Symbol & Measurement & Exp. Sign \\
\hline Value Added of Intellectual Coefficient & VAIC & ICE + CEE & + \\
Economic Performance & ROE & Return on Equity & - \\
Financial Situation & LEV & Financial debts/Equity & + \\
Firm's Age & A & Age at the date of 31/12 & - \\
Degree of Operating Leverage & DOL & \% change in EBIT/\% change in sales & + \\
Firm size & LNA & LN Total Assets & - \\
UnRecorded intangible assets & TQ & (market value of equity+liabilities)/(total assets) & + \\
\hline
\end{tabular}

The natural logarithm of the firm's total assets is included to control for the size of the firm, as larger firms have less systematic and firm specific risk (Binder, 1992; Cheng and Ng, 1992; Wong, 1995). We include Tobin's Q as a control for unrecorded intangible assets other than intellectual capital. Lev (2000) and Kothari et al. (2002) both note that intangible assets increase information asymmetry and thus magnify volatility and variability of firm value. Thus, we expect a significant and positive coefficient estimate on Tobin's Q. We also control for the age of the firm as older firms with longer histories of reported performance have on average less information asymmetry and volatility (Fama and French, 1989; Chincarini et al., 2016). Thus, we expect a negative relation between age and volatility.

Finally, we control for the degree of operating leverage (DOL). Operating leverage is the effect of fixed costs on the variability of earnings before interest and taxes (EBIT). In other words, it is the responsiveness of the firm's EBIT to fluctuations in sales. Following Damodaran, (2014) we calculate DOL as:

$$
\frac{\% \text { change in EBIT }}{\% \text { change in sales }}
$$

Higher values of DOL imply that a firm's profits will vary more greatly due to a given percentage change in sales. Thus, operating leverage correlates to greater volatility in earnings and thus stock returns. This positive relation between has operating leverage and volatility has been documented in the prior literature (Lev, 1974; Myers, 1977; Turnbull, 1977; Gahlon and Gentry, 1982; Mandelker and Ghon Rhee, 1984).

\section{Empirical Results}

\section{Descriptive Statistics}

Table 2 reports descriptive statistics on the variables used in the study for each of the three years used to construct the sample. Firm size of companies in our sample (measured by natural logarithm of total assets) appears stable across the three years. The average levels of both VAIC and Tobin's Q have decreased over the time; this means that probably both the level of intangible assets recognized and the intangible assets not recognized but perceived by financial market have had a decrease. The average level of leverage grew in 2011 as the result of the financial crisis and stabilized by 2016. Similarly, the ROE, albeit always positive, shows the lowest result in 2011. Regarding the dependent variables, the average level of standard deviation remains stable from 2006 to 2011 then decreases in 2016, while beta shows a parabolic trend with the highest average level in 2011.

\section{Multivariate Analysis}

In this section, we estimate regression Equations (1) and (2) to analyze the effect of VAIC on volatility. Table 3 reports the regression results of Equation (1) where Beta is regressed on VAIC and controls. The high R2 value (0.482) supports the goodness of fit of the proposed model. In addition, the small difference between the R2 and the adjusted R2 values demonstrates the adequacy of the number of explanatory variables considered. Lastly, the P-values (F) attest to the significance of the models as a whole (i.e., all variables simultaneously).

As shown in Table 3, all control variables exhibit estimated coefficients in the predicted directions with all but one being statistically significant. More critically for this study, the estimated coefficient on VAIC is positive and statistically significant with a value of 0.0049 (pvalue $\leq 0.05$ ), consistent with our hypothesis. The finding supports the hypothesis that firms with greater values of intellectual capital experience more volatility relative to the market benchmark (i.e. more systematic risk).

Table 4 reports the regression results of Equation (2) where the standard deviation of stock returns is regressed on VAIC and controls. Again the model exhibits a high R2 (0.391), a small difference between the R2 and the adjusted R2 values and highly significant P-values (F). Lev, LNA and Tobin's Q continue to be statistically significant in the predicted directions. ROE and DOL are no longer significant in this model suggesting that they correlate with systematic risk but not idiosyncratic risk. However, now the coefficient estimate on Age is significantly negative as predicted. Most importantly, the coefficient estimate on VAIC continues to be positive $(0.0158)$ and statistically significant ( $p$-value $\leq 0.01)$. 
Table 2: Descriptive statistics

\begin{tabular}{|c|c|c|c|c|c|c|c|}
\hline Var. & Mean & Median & Min & Max & Std. Dev. & Skew. & Kurt. \\
\hline \multicolumn{8}{|c|}{ Panel A: Descriptives Statistics for 2006 Sample } \\
\hline Beta & 0.822 & 0.838 & 0.087 & 1.440 & 0.285 & -0.190 & 2.692 \\
\hline StDv & 0.961 & 0.330 & 0.020 & 14.540 & 1.783 & 4.612 & 27.472 \\
\hline VAIC & 2.638 & 2.080 & -11.370 & 47.110 & 5.923 & 4.680 & 30.552 \\
\hline LNA & 13.230 & 12.890 & 9.830 & 18.300 & 1.816 & 0.699 & 0.057 \\
\hline Lev & 26.814 & 27.850 & 0.170 & 69.280 & 14.877 & 0.308 & 0.213 \\
\hline DOL & 6.704 & 0.236 & -680.000 & 692.360 & 109.583 & 1.036 & 27.798 \\
\hline ROE & 8.476 & 9.650 & -91.500 & 69.340 & 19.222 & -1.541 & 7.414 \\
\hline TQ & 2.157 & 1.340 & 0.580 & 23.710 & 3.008 & 5.227 & 30.965 \\
\hline AGE & 11.623 & 9.000 & 0.000 & 36.000 & 9.403 & 1.204 & 0.801 \\
\hline \multicolumn{8}{|c|}{ Panel B: Descriptive Statistics for 2011 Sample } \\
\hline Beta & 1.131 & 1.141 & 0.390 & 1.749 & 0.290 & -0.147 & 2.450 \\
\hline St.Dv & 0.975 & 0.410 & 0.020 & 14.830 & 1.860 & 4.633 & 26.831 \\
\hline VAIC & 2.389 & 2.015 & -8.720 & 27.680 & 3.730 & 2.895 & 18.201 \\
\hline LNA & 13.302 & 12.938 & 9.561 & 18.850 & 1.870 & 0.718 & 0.247 \\
\hline Lev & 32.485 & 31.965 & 0.030 & 92.140 & 17.540 & 0.362 & 0.489 \\
\hline DOL & 17.929 & 1.608 & $-1,316.000$ & $1,801.000$ & 295.120 & 1.354 & 16.060 \\
\hline ROE & 4.120 & 2.770 & -114.200 & 34.090 & 131.380 & -7.297 & 54.971 \\
\hline TQ & 1.363 & 1.040 & 0.410 & 8.000 & 1.200 & 3.825 & 15.771 \\
\hline AGE & 16.623 & 14.000 & 5.000 & 41.000 & 9.400 & 1.204 & 0.801 \\
\hline \multicolumn{8}{|c|}{ Panel C: Descriptive Statistics for 2016 Sample } \\
\hline Beta & 0.607 & 0.620 & 0.120 & 1.229 & 0.204 & -0.110 & 2.700 \\
\hline St.Dv & 0.555 & 0.220 & 0.010 & 7.780 & 1.011 & 4.186 & 21.897 \\
\hline VAIC & 1.622 & 1.615 & -12.690 & 16.140 & 2.728 & -0.050 & 11.565 \\
\hline LNA & 13.306 & 13.085 & 9.560 & 18.924 & 1.937 & 0.687 & 0.101 \\
\hline Lev & 30.771 & 31.570 & 0.000 & 132.220 & 20.920 & 1.311 & 3.582 \\
\hline DOL & -71.490 & 1.092 & $-10,60.000$ & $1,101.300$ & 962.187 & -10.590 & 113.430 \\
\hline ROE & 5.708 & 3.690 & -109.100 & 137.880 & 43.432 & -3.948 & 30.788 \\
\hline TQ & 1.144 & 0.965 & 0.350 & 5.380 & 0.650 & 3.617 & 17.494 \\
\hline AGE & 21.623 & 19.000 & 10.000 & 46.000 & 9.403 & 1.204 & 0.801 \\
\hline
\end{tabular}

Table 3: Beta multivariate regression analysis

\begin{tabular}{lll}
\hline $\begin{array}{l}\text { Beta }=\text { dependent } \\
\text { variable }\end{array}$ & Coefficient & p-value \\
\hline Intercept & 0.5191 & $0.0002^{* * *}$ \\
VAIC & 0.0049 & $0.0415^{* *}$ \\
ROE & -0.0005 & $0.0156^{* *}$ \\
Lev & 0.0165 & $0.0823^{*}$ \\
LNA & -0.0150 & $0.0974^{*}$ \\
TQ & 0.0232 & $0.0018^{* * *}$ \\
Age & 0.0026 & 0.3183 \\
DOL & 0.6655 & $0.0013^{* *}$ \\
N & 390 & \\
R-squared & 0.482 & \\
Adj. R-squared & 0.471 & \\
P-value (F) & $1.68 \mathrm{e}-06$ & \\
Akaike & 811.8974 & \\
\hline Table 3 repots regresi &
\end{tabular}

Table 3 reports regression analysis output for Equation (1), where Beta is regressed on the variable of interest, VAIC and a set of controls. $*, * *, * * *$ indicate statistical significance at the $0.10,0.05$ and 0.01 levels, respectively. Variable definitions can be found in Table 1 .

Thus, consistent with our expectation, Equation (2) supports the hypothesis that firms with greater values of intellectual capital experience more volatility in stock returns (i.e. more idiosyncratic/specific risk).
Table 4: Std. Dev. Multivariate Regression Analysis

\begin{tabular}{lll}
\hline $\begin{array}{l}\text { Std. Dev. }= \\
\text { dependent variable }\end{array}$ & Coefficient & p-value \\
\hline Intercept & -0.5025 & $0.0071^{* * *}$ \\
VAIC & 0.0158 & $0.0065^{* * *}$ \\
ROE & 0.0006 & 0.2904 \\
Lev & 0.0031 & $0.0016^{* *}$ \\
LNA & -0.0548 & $0.0606^{*}$ \\
TQ & 0.3792 & $<0.0001^{* * *}$ \\
Age & 0.0101 & $0.0973^{* *}$ \\
DOL & -0.0000 & 0.7391 \\
N & 390 & \\
R-squared & 0.391 & \\
Adj. R-squared & 0.385 & \\
P-value(F) & $1.78 \mathrm{e}-06$ & \\
Akaike & 923.32 & \\
\hline
\end{tabular}

Table 4 reports regression analysis output for Equation (2), where Std. Dev. is regressed on the variable of interest, VAIC and a set of controls. ${ }^{*}, * *, * * *$ indicate statistical significance at the $0.10,0.05$ and 0.01 levels, respectively. Variable definitions can be found in Table 1 .

Also worth noting, the coefficient estimate on VAIC in Equation (2) is larger (and statistically significant at a higher level) than in Equation (1). This implies that the VAIC affects the standard deviation of stock returns more than the beta coefficient. 
Controlling for Leverage Ratio and DOL, we verify prior research that theorizes and finds these variables to be determinants of beta (Hamada, 1972; Rubinstein, 1973; Mandelker and Ghon Rhee, 1984), showing that DOL and Leverage Ratio magnify the intrinsic business risk of common stock. Consistent with Banz (1981) and Binder (1992), we find firm size inversely relates to volatility for both specific and systematic risk.

\section{Conclusion}

In this study, we find a significantly positive relation between the extent of a firm's intellectual capital and its stock market volatility/risk (both systematic and idiosyncratic risks). Taken together these results are consistent with the stock market having difficulty measuring the intangible intellectual capital and/or knowledge-based economies that rely on intellectual capital being more dynamic and inherently volatile.

In both models, we verify that VAIC and Tobin's q are significantly positively related to the volatility of firm. Additionally, models estimate that both VAIC and Tobin's Q have a greater impact (larger estimated regression coefficients with more or similar levels of statistical significance) on the standard deviation of returns than market beta. This novel finding adds to the literature by showing intangible assets, including intellectual capital, are important determinants of firm's specific risk.

Prior literature has examined how intellectual capital relates to firm value reflected in the stock market. We contribute to this literature around intellectual capital and stock market behavior by providing evidence concerning the relation between intellectual capital and a key stock market characteristic, volatility. Understanding this relation should have many practical benefits for investors tasked with understanding the risks inherent to particular investments and whether those risks can be diversified away or are sufficiently compensated for with higher returns. Additionally, understanding this relation is of use to regulators tasked with maintaining stability within markets while operating with scarce resources.

\section{Acknowledgement}

The Authors sincerely thanks for the help of colleagues and the collecting-data team to support the success of this article.

\section{Author's Contributions}

Brett W. Cantrell: Contributed to the writing/editing of the manuscript, organization of the study, discussion and conclusion, and the structure of the manuscript.

Daniela Coluccia, Stefano Fontana and Silvia Solimene: Contributed to the Theoretical Background of the manuscript, Development of the Hypothesis and Statistical Model, and Discussion/Conclusion.

\section{Ethics}

This article is original and contains unpublished material. The corresponding author confirms that all of the other authors have read and approved the manuscript and no ethical issues involved.

\section{References}

Alipour, M., 2012. The effect of intellectual capital on firm performance: an investigation of Iran insurance companies. Measuring Bus. Excellence, 16: 53-66. DOI: $10.1108 / 13683041211204671$

Alshubiri, F.N., 2015. Impact of intellectual capital from market capitalization on profitability in financial sector of Oman. Mediterranean J. Social Sci., 6: 54-60. DOI: 10.5901/mjss.2015.v6n2p54

Appuhami, R. and M. Bhuyan, 2015. Examining the influence of corporate governance on intellectual capital efficiency: Evidence from top service firms in Australia. Managerial Auditing J., 30: 347-372. DOI: $10.1108 /$ MAJ-04-2014-1022

Banz, R.W., 1981. The relationship between return and market value of common stocks. J. Financial Economics, 9: 3-18. DOI: $10.1016 / 0304-405 X(81) 90018-0$

Bartram, S.M., G.W. Brown and W. Waller, 2015. How important is financial risk? J. Financial Quantitative Analysis, 50: 801-824. DOI: $10.1017 / \mathrm{S} 0022109015000216$

Binder J., 1992. Beta, firm size and concentration. Economic Inquire, 30: 556-563. DOI: $10.1111 /$ j.1465-7295.1992.tb01981.x

Bontis, N., 1998. Intellectual capital: An exploratory study that develops measures and models. Management Decision, 36: 63-76. DOI: $10.1108 / 00251749810204142$

Brandt, M.W., A. Brav, J.R. Graham and A. Kumar, 2010. The idiosyncratic volatility puzzle: Time trend or speculative episodes? Rev. Financial Studies, 23: 863-899. DOI: 10.1093/rfs/hhp087

Brennan, N., 2001. Reporting intellectual capital in annual reports: Evidence from Ireland. Accounting Auditing Accountability J., 14: 423-437. DOI: $10.1108 / 09513570110403443$

Campbell, J.Y., M. Lettau, B.G. Malkiel and Y. Xu, 2001. Have individual stocks become more volatile? An empirical exploration of idiosyncratic risk. J. Finance, 56: 1-43. DOI: 10.1111/0022-1082.00318

Cassiman, B. and R. Veugelers, 2006. In search of complementarity in innovation strategy: Internal R\&D and external knowledge acquisition. Management Sci., 52: 68-82.

DOI: $10.1287 / \mathrm{mnsc} .1050 .0470$ 
Chen, J., Z. Zhu and H.Y. Xie, 2004. Measuring intellectual capital: A new model and empirical study. J. Intellectual Capital, 5: 195-212. DOI: $10.1108 / 14691930410513003$

Cheng, Y. and N.K. Ng, 1992. Stock price dynamics and firm size: An empirical investigation. Journal Finance, 47: 1985-1997. DOI: $10.1111 /$ j.1540-6261.1992.tb04693.x

Chincarini, L.B., D. Kim and F. Moneta, 2016. The life cycle of beta. Working paper.

Christie, A., 1982. The stochastic behavior of common stock variances value, leverage and interest rate effects. J. Financial Economics, 10: 407-432. DOI: 10.1016/0304-405X(82)90018-6

Coluccia, D., S. Fontana and S. Solimene, 2017. The influence of voluntary disclosure on the volatility of firms from a multi-stakeholder perspective. Int. J. Managerial Financial Accounting, 9: 44-67. DOI: 10.1504/IJMFA.2017.084049

Damodaran, A., 2014. Applied Corporate Finance, 4th Edn., John Wiley \& Sons Inc., ISBN-10: 1118918568, pp: 656.

Daniel, K. and S. Titman, 2006. Market reactions to tangible and intangible information. J. Finance, 61: 1605-1643.

DOI: 10.1111/j.1540-6261.2006.00884.x

Daum, J.H., 2002. Beyond budgeting: A model for performance management and controlling in the $21 \mathrm{st}$ century. Controlling \& Finance.

Edvinsson, L. and M.S. Malone, 1997. Intellectual capital: realizing your company's true value by finding its hidden brainpower. New York, Harper Collins Publishers, Inc.

Edvinsson, L., 1997. Developing intellectual capital at Skandia. Long Range Planning, 30: 366-373. DOI: 10.1016/S0024-6301(97)90248-X

Elton, E.J., M.J. Gruber and C.R. Blake, 2003. Incentive fees and mutual funds. J. Finance, 58: 779-804. DOI: $10.1111 / 1540-6261.00545$

Engle, R.F., 1982. Autoregressive conditional heteroscedasticity with estimates of the variance of United Kingdom inflation. Econometrica, 50: 9871008. DOI: $10.2307 / 1912773$

Erikson, T., 2002. Entrepreneurial capital: The emerging venture's most important asset and competitive advantage. J. Bus. Venturing, 17: 275-291. DOI: $10.1016 / \mathrm{S} 0883-9026(00) 00062-8$

Fama, E., 1976. Foundations of finance: Portfolio decisions and securities prices. New York: Basic Books.

Fama, E.F. and K.R. French, 1989. Business conditions and the expected returns on bonds and stocks. J. Financial Economics, 25: 23-50. DOI: $10.1016 / 0304-405 X(89) 90095-0$
Firer, S. and S. Williams, 2003. Intellectual capital and traditional measures of corporate performance. J. Intellectual Capital, 4: 348-360. DOI: $10.1108 / 14691930310487806$

Gahlon, J.M. and J.A. Gentry, 1982. On the relationship between systematic risk and the degree of operating and financial leverage. Financial Management, 11: 15-23. DOI: $10.2307 / 3665021$

Goldfinger, C., 1997. Understanding and measuring the intangible economy: Current status and suggestions for future research. CIRET seminar. Helsinki.

Goyal, A. and P. Santa-Clara, 2003. Idiosyncratic risk matters! J. Finance, 58: 975-1007. DOI: $10.1111 / 1540-6261.00555$

Hamada, R.S., 1972. The effect of the firm's capital structure on the systematic risk of common stocks. J. Finance, 27: 435-452. DOI: $10.1111 / \mathrm{j} .1540-6261.1972 . t b 00971 . x$

Hayton, J.C., 2005. Competing in the new economy: The effect of intellectual capital on corporate entrepreneurship in high-technology new ventures. R\&D Management, 35: 137-155. DOI: $10.1111 / \mathrm{j} .1467-9310.2005 .00379 . \mathrm{x}$

Hejazi, R., M. Ghanbari and M. Alipour, 2016. Intellectual, human and structural capital effects on firm performance as measured by Tobin's Q. Knowledge Process Management, 23: 259-273. DOI: $10.1002 / \mathrm{kpm} .1529$

Junkin, K., 2012. Macroeconomic determinants of stock market behaviour in South Africa. Rhodes University: South Africa.

Kianto, A., P. Hurmelinna-Laukkanen and P. Ritala, 2010. Intellectual capital in service- and product-oriented companies. J. Intellectual Capital, 11: 305-325. DOI: $10.1108 / 14691931011064563$

Kong, E., 2008. The development of strategic management in the non-profit context: Intellectual capital in social service non- profit organizations. Int. J. Management Rev., 10: 281-299. DOI: $10.1111 /$ j.1468-2370.2007.00224.x

Kothari, S.P., T. Laguesse and A. Leone, 2002. Capitalization versus expensing: Evidence on the uncertainty of future earnings from current investments in PP\&E versus R\&D. Review Accounting Studies, 7: 355-382. DOI: $10.1023 / \mathrm{A}: 1020764227390$

Laing, G., J. Dunn and S. Hughes-Lucas, 2010. Applying the VAIC ${ }^{\text {TM }}$ model to Australian hotels. J. Intellectual Capital, 11: 269-183. DOI: $10.1108 / 14691931011064545$

Lev, B. and P. Zarowin, 1999. The boundaries of financial reporting and how to extend them. J. Accounting Res., 37: 353-385. DOI: $10.2307 / 2491413$ 
Lev, B., 1974. On the association between operating leverage and risk. J. Financial Quantitative Analysis, 9: 627-641. DOI: 10.2307/2329764

Lev, B., 2000. Intangibles management, measurement and reporting. Harrisonburg, Virginia: Bookings Institution Press.

Maditinos, D., D. Chatzoudes, C. Tsairidis and G. Theriou, 2011. The impact of intellectual capital on firms' market value and financial performance. J. Intellectual Capital, 12: 132-151. DOI: $10.1108 / 14691931111097944$

Mandelker, G.N. and S. Ghon Rhee, 1984. The impact of the degrees of operating and financial leverage on systematic risk of common stock. J. Financial Quantitative Analysis, 19: 45-57.

DOI: $10.2307 / 2331000$

Markowitz, H.M., 1952. Portfolio selection. J. Finance, 7: 77-91. DOI: 10.1111/j.1540-6261.1952.tb01525.x

Martinez-Torres, M.R., 2006. A procedure to design a structural and measurement model of intellectual capital: An exploratory study. Information Management, 43: 617-626.

DOI: $10.1016 /$ j.im.2006.03.002

Mayer, R.C., J.H. Davis and F.D. Schoorman, 1995. An integrative model of organizational trust. Academy Management Rev., 20: 709-734. DOI: $10.2307 / 258792$

Mazzucato, M. and M. Tancioni, 2007. Stock price volatility and patent citation dynamics. The Case of Pharmaceutical Industry. Innogen Working Paper No. 64.

Mazzucato, M. and M. Tancioni, 2012. R\&D, Patents and Stock Return Volatility. J. Evolutionary Economics, 22: 811-832.

Miller, M.H. and F. Modigliani, 1961. Dividend policy, growth and the valuation of shares. J. Bus., 34: 411-433. DOI: 10.1086/294442

Myers, S.C., 1977. The Relation between Real and Financial Measures of Risk and Return. In: Risk and Return in Finance, I. Friend and J.L. Bicksler (Eds.), Cambridge: Ballinger Publishing Company.

Nunamaker, J. F. Jr., N.C. Romano Jr. and R.O. Briggs, 2002. Increasing intellectual bandwidth: Generating value from intellectual capital with information technology. Group Decision Negotiation, 11: 69-86. DOI: $10.1023 / \mathrm{A}: 1015201126568$

Nuryaman, 2012. The influence of corporate governance practices on the company's financial performance. J. Global Bus. Economic.

Nuryaman, 2015. The influence of intellectual capital on the firm's value with the financial performance as intervening variable. Procedia - Social Behavioral Sci., 211: 292-298.

Pamela, M. and K. Mark, 1993. The impact of intangible capital on Tobin's Q in the semiconductor industry. Am. Economic Rev., 83: 265-269.
Petty, R. and J. Guthrie, 2000. Intellectual capital literature review: Measurement, reporting and management. J. Intellectual Capital, 1: 155-176. DOI: $10.1108 / 14691930010348731$

Poon, S.H. and C. Granger, 2003. Forecasting volatility in financial markets. J. Economic Literature, 41: 478-539. DOI: $10.1257 /$ jel.41.2.478

Poraghajan, A., A. Ramezani and S. Mohammadzadeh, 2013. Impact of intellectual capital on market value and firms' financial performance: Evidences from Teheran Stock Exchange. World Sci. J., 1: 197-208.

Pulic, A., 2000. VAIC ${ }^{\text {TM }}$ - an accounting tool for IC management. Int. J. Technology Management, 20: 702-714. DOI: 10.1504/IJTM.2000.002891

Pulic, A., 2004. Intellectual capital - does it create or destroy value? Measuring Bus. Excellence, 8: 62-68. DOI: $10.1108 / 13683040410524757$

Roos, J., L. Edvinsson and N.C. Dragonetti, 1997. Intellectual capital. Navigating the New Business Landscape. London: Palgrave, Mcmillan.

Rubinstein, M.E., 1973. A mean-variance synthesis of corporate financial theory. J. Finance, 28: 167-182. DOI: $10.1111 /$ j. 1540-6261.1973.tb01356.x

Salchi, M., G. Enayati and P. Javadi, 2014. The relationship between intellectual capital with economic value added and financial performance. Iranian J. Management Studies, 7: 245-269.

Sällebrant, T., J. Hansen, N. Bontis and P. HofmanBang, 2007. Managing risk with intellectual capital statements. Management Decision, 45: 1470-1483. DOI: $10.1108 / 00251740710828717$

Schiuma, G. and A. Lerro, 2008. Knowledge-based capital in building regional innovation capacity. J. Knowledge Management, 12: 121-136. DOI: $10.1108 / 13673270810902984$

Schwert, G.W., 1989. Why does stock market volatility change over time? J. Finance, 44: 1115-1153. DOI: 10.1111/j.1540-6261.1989.tb02647.x

Sharpe, W.F., 1964. Capital asset prices: A theory of market equilibrium under conditions of Risk. J. Finance, 19: 425-442. DOI: 10.2307/2977928

Stewart, T., 1997. Intellectual capital, the new wealth of organization. New York: Doubleday.

Sullivan, Jr., P.H. and P.H. Sullivan, Sr., 2000. Valuing intangibles companies - An intellectual capital approach. J. Intellectual Capital, 1: 328-340. DOI: $10.1108 / 14691930010359234$

Sumedrea, S., 2013. Intellectual capital and firm performance: A dynamic relationship in crisis time. Procedia Economics Finance, 6: 137-144. DOI: 10.1016/S2212-5671(13)00125-1

Sveiby, K.E., 1997. The new organizational wealth: Managing and measuring knowledge-based assets. San Francisco: Berrett Loehler Publishers Inc. 
Tudor, A.T., S. Dima, B. Dima and R.V. Ratiu, 2014. The linkage between intangibles and profitability. Annals Universitatis Apulensis Series Oeconomica 16: 283-293.

Turnbull, S.M., 1977. Market value and systematic risk. Journal Finance, 32: 1125-1142. DOI: $10.1111 /$ j.1540-6261.1977.tb03315.x

Volkov, A., 2012. Value added intellectual co-efficient (VAIC): A selective thematic-bibliography. Journal New Business Ideas Trends, 10: 14-24.

Wang, W.Y. and C. Chang, 2005. Intellectual capital and performance in causal models: Evidence from the information technology industry in Taiwan. J. Intellectual Capital, 6: 222-236.

DOI: $10.1108 / 14691930510592816$
Wei, S.G. and C. Zhang, 2006. Why did individual stocks become more volatile? J. Bus., 79: 259-292. DOI: $10.1086 / 497411$

Wong, K.P., 1995. Effect of wage rate on systematic risk in a Cournot duopoly. J. Economics Bus., 46: 227-233. DOI: 10.1016/0148-6195(94)90015-9

Wu, Y.W., M.L. Chang and C.W. Chen, 2006. Promoting innovation through the accumulation of intellectual capital, social capital and entrepreneurial orientation. R\&D Management, 38: 265-277. DOI: $10.1111 /$ j.1467-9310.2008.00512.x

Zanda, G., 2012. Corporate management in a knowledge-based economy. London: Palgrave MacMillan. 